\title{
Wheat improves nitrogen use efficiency of maize and soybean-based cropping systems
}

A.C.M. Gaudin, K. Janovicek, B. Deen, and D.C. Hooker

This is a post-peer-review, pre-copy edit version of an article published in Agriculture, Ecosystems \& Environment. The final authenticated version is available online at: http://dx.doi.org/10.1016/..agee.2015.04.034.

Suggested Citation: Gaudin, A.C.M., Janovicek, K., Deen, B., et al. Wheat improves nitrogen use efficiency of maize and soybean-based cropping systems.

Agric Ecosyst Environ 210, 1-10 (2015).

http://dx.doi.org/10.1016/j.agee.2015.04.034

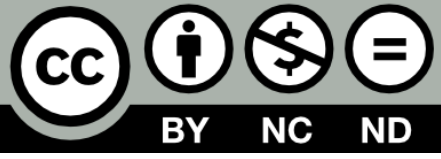


1 Wheat Improves Nitrogen Use Efficiency of Ontario Maize and Soybean-

\section{Based Cropping Systems}

Amélie C.M Gaudin ${ }^{a 1}$, Ken Janovicek ${ }^{b}$, Bill Deen ${ }^{b}$, David C. Hooker ${ }^{c}$

6 a University of California Davis, Department of Plant Sciences, One Shields

7 Avenue, Davis, CA 95616, USA

8 b University of Guelph, Department of Plant Agriculture, Crop Science Building, 50

9 Stone Road East, Guelph, ON N1G 2W1, Canada

10 ' University of Guelph, Department of Plant Agriculture, Ridgetown Campus,

11 Ridgetown, ON NOP 2C0, Canada

12

$13{ }^{1}$ Corresponding author permanent address

14 Amélie C.M Gaudin: agaudin@ucdavis.edu

$15 \quad(530)-752-1212$

16 University of California Davis

17 Department of Plant Sciences

182136 PES Building, One Shields Ave

19 Davis, CA 95616, USA

20 Authors email

21 Ken Janovicek: kjanovic@uoguelph.ca

22 Bill Deen: bdeen@uoguelph.ca

23 David C.Hooker: dhooker@uoguelph.ca 


\section{Abstract}

25 Integrated nitrogen (N) management strategies could make significant

26 contributions to improving the efficiency of $\mathrm{N}$ use in the northern Corn Belt,

27 particularly for maize, which has high $\mathrm{N}$ requirements. Using legume cover crops

28 has been shown to increase both the soil's capacity to supply $\mathrm{N}$, and Nitrogen Use

29 Efficiency (NUE), through the reduction in the amount of $\mathrm{N}$ fertilizer that must be

30 applied to the following crops. However, the impact of non-legume crops such as

31 winter wheat (Triticum aestivum L.) on the diminishing return function between

32 crop yield and $\mathrm{N}$ supply and its influence on $\mathrm{N}$ fertilizer use remains unclear. We

33 hypothesized that maintaining wheat in short maize and soybean- based rotations

34 is instrumental to improve cropping system performance and increase $\mathrm{N}$ fertilizer

35 use efficiency while decreasing $\mathrm{N}$ requirements for maize. Seven maize and

36 soybean rotations with different frequency of winter wheat with or without

37 underseeded red clover (Trifolium pratense L.) were grown in two tillage systems

38 (conventional and zone-tillage) and four long-term $\mathrm{N}$ regimes in Ridgetown, ON,

39 Canada (2009-2013). Wheat in the rotation increased maize and soybean yields,

40 negated crop yield lags due to zone-tillage, and decreased maximum economic

41 rates of fertilizer $\mathrm{N}(\mathrm{MERN})$. The benefits of wheat in the rotation on maize yield

42 were negated by high $\mathrm{N}$ rates; however, similar yields were obtained with lower $\mathrm{N}$

43 levels in rotationally grown maize, resulting in a $17 \%$ (conventional till) to $21 \%$

44 (zone-till) increase in Partial Factor Productivity for $\mathrm{N}$ fertilizer at MERN (PFPMERN).

45 While $\mathrm{N}$ benefits to crops following wheat alone may be attributed to a higher

46 indigenous plant available soil $\mathrm{N}$, underseeding red clover further increased the 
47 agronomic efficiency $(A E)$ of $N$ fertilizer $\left(A E_{\text {MERN }}\right)$ up to $32 \%$. Maize yields were 48 also less limited by $N$ supply and less responsive to $N$ fertilization when grown in

49 rotation with wheat, especially in the zone-till system. These results highlight the

50 value of wheat as a system component of dominant maize/soybean short rotations

51 of Ontario and its potential to increase both maize and soybean productivity using

52 less $\mathrm{N}$ input.

53

54 Keywords: nitrogen, wheat, maize, soybean, nitrogen use efficiency, MERN, 55 rotation diversity. 


\section{1. Introduction}

57 Over the past several decades, crop diversity in the northern Corn Belt (Ontario

58 and North Central US) has substantially declined and rotations consisting solely of

59 maize and/or soybean increasingly dominate the landscape (Figure 1). Increases

60 in maize and soybean acreage has corresponded with reductions in acreages of

61 grasslands, forages and other small cereal grains (Figure 1) (Liebman et al., 2013;

62 Nickerson et al., 2007; Wright and Wimberly, 2013).

63 Agronomic and environmental consequences of declining rotation diversity have

64 been well documented. Loss of rotation diversity has been associated with

65 reductions in soil organic matter, aggregate stability and soil quality (Dapaah and

66 Vyn, 1998; Havlin et al., 1990; Katsvairo et al., 2002; McDaniel et al., 2014;

67 Munkholm et al., 2013; Raimbault and Vyn, 1991; Van Eerd et al., 2014; Varvel,

68 1994), increased soil erosion (Langdale et al., 1991; Rachman et al., 2003; Tisdall

69 and Oades, 1982), increased greenhouse gas emissions (Drury et al., 2008; Liebig

70 et al., 2005; Meyer Aurich et al., 2006), decrease in yield potential and increased

71 yield instability (Grover et al., 2009; Katsvairo and Cox, 2000; Lund et al., 1993;

72 Meyer-Aurich et al., 2006; Singer and Cox, 1998; Smith et al., 2008; Stanger and

73 Lauer, 2008; Varvel, 2000; Yamoah et al., 1998a).

74 Many of the agronomic and environmental consequences associated with losses

75 of crop rotation diversity also influence soil nitrogen $(\mathrm{N})$ processes, $\mathrm{N}$ losses and

76 crop response to N (Culman et al., 2013; Havlin et al., 1990; McDaniel et al., 2014;

77 Shipitalo et al., 2013; Stecker et al., 1995; Varvel and Peterson, 1990). For

78 instance, there is considerable evidence that removal of legumes, such as alfalfa 
79 (Medicago sativa L.), red clover (Trifolium pratense L.) or soybean (Glycine max

80 (L.) Merr.) from a maize (Zea mays L.) based rotation increase optimum $\mathrm{N}$

81 fertilization rates and have a significant impact on $\mathrm{N}$ dynamics (Bruulsema and

82 Christie, 1987; Gentry et al., 2013; Henry et al., 2010; Hesterman et al., 1992;

83 Liebman et al., 2012; Stecker et al., 1995; Stute and Posner, 1995; Wivstad, 1999).

84 Furthermore, increasing $\mathrm{N}$ fertilization has also been shown to decrease rotational

85 benefits of legumes on maize yields in various studies (Adams et al., 1970;

86 Copeland and Crookston, 1992; Crookston et al., 1991; Nevens and Reheul, 2001;

87 Peterson and Varvel, 1989; Porter et al., 1997; Riedell et al., 1998; Singer and

88 Cox, 1998; Stecker et al., 1995). However, much less is known when non-legume

89 species, such as winter wheat (Triticum aestivum L.), are removed from common

90 maize-based rotations in the northern Corn Belt.

91 The potential effect of rotation diversity on crop response to $\mathrm{N}$ fertilization is of

92 interest given escalating $\mathrm{N}$ fertilizer costs (USDA-NASS, 2014a) and continuing

93 concerns about the negative impact of fertilizer $\mathrm{N}$ production and potential losses

94 on environmental quality (Lebender et al., 2014; Peoples et al., 2004; Syswerda et

95 al., 2012). Increasing N Use Efficiency (NUE) has also been a long-lasting

96 research goal, particularly for maize, which is a major user of $\mathrm{N}$. Although the

97 amount of maize grain produced per unit of $\mathrm{N}$ applied $\left(P F P_{N}\right)$ in the United States

98 has increased linearly by $36 \%$ in the last 21 years (from $42 \mathrm{~kg} \mathrm{~kg}^{-1}$ in 1980 to 57

$99 \mathrm{~kg} \mathrm{~kg}^{-1}$ in 2000), due to a combination of high yielding hybrids and improvement

100 in crop management, the amount of $\mathrm{N}$ fertilizer recovered in aboveground plant

101 biomass during the growing season $\left(\mathrm{RE}_{\mathrm{N}}\right)$ remains relatively low ( $\sim 37 \%$ across 
102 various rotations in the North-Central USA (Cassman et al., 2002), and significant

103 opportunities remain to improve $\mathrm{N}$ fertilizer use practices in maize. For instance,

104 the impact of wheat in maize-soybean rotations on the diminishing return function

105 between maize yield and N supply and NUE is not well understood.

106 We hypothesized that maintaining crop rotation diversity is instrumental to increase

107 productivity, maize $\mathrm{N}$ fertilizer use efficiency and decrease crop $\mathrm{N}$ requirements.

108 We used yield data (2009-2013) gathered at a long-term $\mathrm{N}$ regime and rotation

109 trial to quantify benefits of maintaining wheat in short maize- and soybean-based

110 rotations on: 1) cropping system's productivity, 2) crop N requirements, 3) NUE,

111 and 4) whether the temporal niche provided by winter wheat for red clover or tillage

112 system influences these responses.

114 2. Material and Methods

$115 \quad$ 2.1.Study site

116 Research was conducted from 2009 to 2013 on a field trial that was established at

117 the University of Guelph Ridgetown Campus, Ridgetown, ON $\left(42^{\circ} 26^{\prime} \mathrm{N}, 81^{\circ} 53^{\prime} \mathrm{W}\right)$

118 in 1995 . The soil was an Orthic Humic Gleysol clay loam with $1.6 \%$ to $2.3 \%$ organic

119 carbon in the top $15 \mathrm{~cm}$ in 2009 (Van Eerd et al., 2014). Weather data were

120 recorded on-site at $\sim 200 \mathrm{~m}$ from the experiment; data included hourly air

121 temperature at $1.25 \mathrm{~m}$ above the soil surface and daily rainfall. Average monthly

122 temperature and precipitation for the last decade (2003-2013) are shown in Figure

123 2A. Deviations from monthly long-term averages for both temperature and

124 precipitation during the study are presented in Figure 2 B,C. 
126 Since 1995, treatments were established annually on the same plots and were

127 arranged as a split-split plot design with four replications. The treatments were

128 tillage system on the main plot, crop rotation on the split-plot and $\mathrm{N}$ rates on the 129 split-split-plot.

130 The main-plot treatment consisted of two tillage systems: conventional and zone-

131 till for maize. For maize and soybean, conventional tillage consisted of moldboard

132 plowing in the fall at a depth of $0.20 \mathrm{~m}$, followed by two or three passes with a field

133 cultivator in the spring at a depth between 0.07 to $0.08 \mathrm{~m}$. Prior to 2012 , the zone-

134 till treatment for maize consisted of two planter-mounted coulters per row. In 2012,

135 the zone-till maize treatment was modified by tilling zones in the fall using a Trans-

136 Till (Row-tech, Snover, MI, USA) since very few local maize growers use no-till

137 practices on similar fine-textured soils because of unfavorable seedbeds or delays

138 in maize planting (Vyn and Hooker, 2002). Maize was then planted into these tilled

139 zones in the spring with the same planter equipped with two coulters per row. In

140 all years of the long-term trial for maize, the inter-row spaces where left

141 undisturbed.

142 From 1995 to 2008, the split-plot consisted of five crop rotation regimes:

143 continuous maize (MM), continuous soybean (SS), maize-soybean (MS),

144 soybean-winter wheat (SW) and maize-soybean-winter wheat (MSW). In 2009, a

145 red clover treatment was introduced by frost seeding into the wheat stand in March

146 of every year in all wheat plots by splitting across the width. This resulted in two

147 additional rotation treatments from 2009-2013: SW with the wheat underseeded to 
148 red clover (SWrc) and MSW with the wheat underseeded to red cover (MSWrc).

149 Crop rotations with more than one crop were duplicated or triplicated so that all

150 crops within each rotation were present in every year. Impact of the red clover split

151 implemented in 2009 on crop yields could be first measured in 2011 for soybean

152 (SW vs SWrc) and 2012 for maize (MSW vs MSWrc). Since no significant effects

153 of red clover history could be detected in 2010 or across study years (Figure 3),

154 yield data from 2010 and onward were used for all rotations.

155 The split-split-plot treatment consisted of four $\mathrm{N}$ rates in the maize and wheat. No

$156 \mathrm{~N}$ fertilizer was applied to soybean. Each maize and wheat split-plot (6.1-m wide

$157 \times 24-m$ long) was divided along the length to represent the four $\mathrm{N}$ rate treatments,

158 which were kept consistent across the whole duration of the rotation since the 159 experiment was established in 1995. From 2009 to 2013 , total $\mathrm{N}$ rates for maize 160 were $12,72,132$, and $192 \mathrm{~kg} \mathrm{~N} \mathrm{ha}^{-1}$, and $0,50,100$, and $150 \mathrm{~kg} \mathrm{ha}^{-1}$ for wheat. In 161 maize, $\mathrm{N}$ treatments consisted of $12 \mathrm{~kg} \mathrm{~N} \mathrm{ha}^{-1}$ applied as a starter fertilizer (150 kg 162 ha $^{-1}$ of 8-32-16) on all treatments, with the balance of $\mathrm{N}$ sidedress-applied as urea 163 ammonium nitrate (28-0-0) at about the V3 developmental stage. The UAN was 164 knifed-in or injected at $10 \mathrm{~cm}$ deep between crop rows. In winter wheat, $100 \mathrm{~kg} \mathrm{ha}$ 1651 of monoammonium phosphate (11-52-0 or MAP) was applied at planting, 166 followed by urea (46-0-0) or ammonium nitrate (33-0-0) at Zadoks 21 up to the 167 target $\mathrm{N}$ rate. All $\mathrm{N}$ rates used in the analysis include the total $\mathrm{N}$ applied in both the 168 starter and in-crop applications and were not adjusted when red clover was 169 included in the rotation. From 1995 to $2008, \mathrm{~N}$ rates ranged from 0 to $150 \mathrm{~kg} \mathrm{~N}$ ha-

$170{ }^{1}$ and 0 to $120 \mathrm{~kg} \mathrm{~N} \mathrm{ha}^{-1}$ in maize and wheat respectively. 
172 The cultivars planted along with planting and harvesting dates are presented for

173 each crop in Table A.1. From 2009 to 2013, maize was seeded at 84,000 seeds

$174 \mathrm{ha}^{-1}$ in $0.76 \mathrm{~m}$-wide rows with a 4-row no-till planter (John Deere 7000, Moline, IL).

175 Soybean was seeded at 400,000 seeds $\mathrm{ha}^{-1}$ in $0.38 \mathrm{~m}$-wide rows with an eight-

176 row-unit no-till planter (Kearney Planters Inc., Thamesville, ON). Wheat was

177 seeded at 1,600,000 seeds ha-1 and single-cut red clover was frost-seeded at 10

$178 \mathrm{~kg} \mathrm{ha}^{-1}$ in early March. The same maize, soybean, and wheat cultivars were never

179 planted for more than two successive years throughout the study (Table A.1), and

180 they were chosen according to their popularity among local growers. Weeds were

181 controlled in maize and soybean with both pre- and post-emergent herbicides. In

182 wheat, post-emergent herbicides were applied when needed. Plots were

183 maintained so that pests and weed pressure did not differ between treatments and

184 that productivity was not adversely affected by those factors.

185 The middle two rows of each four-row-plot were harvested for yield determinations

186 in maize, and a 1.5-m wide swath was harvested from the middle rows of each

187 soybean and wheat plot. In all years of the experiment, crop residues were

188 returned to the plot area after the grain was harvested. Grain yields, grain

189 moistures, and test weights were measured on plot combines equipped with

190 HarvestMaster GrainGage Classic grain measurement systems (Juniper Systems,

191 Inc., Logan, UT). Red clover plant population densities were estimated visually in

192 September between 2009 and 2013.

193 2.4 Crop response to Nitrogen 
194 Regression analyses were performed using treatment means across years to 195 estimate maize and winter wheat grain yields at increasing $N$ rates from 2010 to

196 2013. Grain yields were not estimated beyond $192 \mathrm{~kg} \mathrm{~N}^{-1}$ in maize and $150 \mathrm{~kg}$ $197 \mathrm{~N} \mathrm{ha}^{-1}$ in wheat.

198 The impact of $\mathrm{N}$ fertilization on crop-specific rotational benefits to maize yields was 199 measured by fitting regression models to the estimated delta $(\Delta)$ yield between two 200 treatments (Table 2). Nmax was calculated from regression equations, and was 201 defined as the $\mathrm{N}$ rate at which grain yields (Nmaxy) or rotational effects $\left(\mathrm{Nmax}_{\mathrm{r}}\right)$ 202 was maximized for each treatment.

203 The Maximum Economic Rate of Nitrogen (MERN, $\mathrm{kg} \mathrm{N} \mathrm{ha}^{-1}$ ) was defined as the $204 \mathrm{~N}$ rate that produced maximum return to $\mathrm{N}$ investments and Maximum Economic 205 Yield (MEY, kg grain yield ha ${ }^{-1}$ ). MERN was calculated from quadratic regression 206 equations describing the maize yield responses to fertilizer N (Gaudin et al., 2014; 207 Rajsic and Weersink, 2008; Vyn et al., 2000):

$208[1] \mathrm{MERN}=[\mathrm{b}-(\mathrm{F} / \mathrm{P})] / 2 \mathrm{c}$

209 where $b$ and $c$ are linear and quadratic coefficients from the yield response 210 equations (yield $\left.=a+b N+c N^{2}\right), F$ is the cost of fertilizer $N\left(C A N \$ k g^{-1}\right)$ and $P$ is 211 the price of maize $\left(\mathrm{CAN} \$ \mathrm{~kg}^{-1}\right)$. The average farm value of maize and cost of urea 212 fertilizer in Ontario from $08 / 2009$ to $08 / 2013$ were used (CAN $\$ 0.22 \mathrm{~kg}^{-1}$ of maize 213 at farm value and CAN $\$ 1.54 \mathrm{~kg}^{-1}$ of $\mathrm{N}$ as urea, OMAFRA 2014).

214 Partial Factor Productivity for $\mathrm{N}$ fertilizer at economic optimums (PFPMERN, , 215 Cassman et al., 2002) represents yields obtained per unit of $\mathrm{N}$ applied at MERN 216 for each rotation and tillage treatments $\left(P F P_{M E R N}=M E Y / M E R N\right)$. Agronomic 




218 differential plant available soil $\mathrm{N}$ of the different treatments in NUE calculation:

219 [2] $\mathrm{AE}_{\text {MERN }}\left(\mathrm{kg} \mathrm{kg} \mathrm{N}^{-1}\right)=\left(\left(\mathrm{MEY}-\mathrm{Y}_{\mathrm{N}=0}\right) / \mathrm{MERN}\right)$

220 where $Y_{N=0}$ is the yield intercept (a) of the $N$ response curves. Incremental

221 Agronomic Efficiencies of $\mathrm{N}$ fertilizer $\left(A E_{i}\right.$, Cassman et al., 2003) estimate yield

222 gains obtained per unit of incremental $\mathrm{N}$ rate:

223 [3] $A E_{i}\left(\mathrm{~kg} \mathrm{~kg} \mathrm{~N}^{-1}\right)=\mathrm{dY} / \mathrm{dF}=\left(\right.$ Yield $_{\mathrm{N}}-$ Yield $\left._{\mathrm{N}-1}\right) /\left(\mathrm{N}\right.$ rate $\mathrm{N}_{\mathrm{N}}-\mathrm{N}$ rate $\left.{ }_{\mathrm{N}-1}\right)$

$224 \quad 2.5$ Statistical Methods

225 Statistical analyses were performed using SAS statistical software (Statistical

226 Analysis System, version 9.3, SAS institute, NC, USA). Residuals were found

227 homogeneous, normal-distributed using the Shapiro-Wilk $W$ test $(P=0.98)$ and no

228 significant outliers were detected by Lund's test. Mixed models were used for

229 analysis of variance, with crop rotation, tillage system and $\mathrm{N}$ as fixed effects, and

230 year and replication as random effects. PROC NLIN with Marquardt iterative

231 method was used to fit crop yield response to $\mathrm{N}$ rate to quadratic plateau models.

232 Models were constrained such that the linear regression coefficient was greater

233 than or equal to 0 , and the quadratic coefficient was less or equal to 0 (Gaudin et

234 al, 2014). Comparison of predicted values from regression curves were based on

235 a t-test using standard errors obtained from the Mixed model. Type I error rate was

236 set at 0.05 for all tests.

237 3. Results

$238 \quad 3.1$ Winter wheat in rotation increases maize and soybean yields 
239 Inclusion of winter wheat in the crop rotation increased maize and soybean yields,

240 but the magnitude of impact depended on the tillage system in both crops (Table

241 1). Crop rotation with winter wheat increased soybean yields by 0.61 and $0.32 \mathrm{Mg}$

242 ha $^{-1}$ in tilled and zone-tilled systems, respectively $(P<0.05$; Figure 4$)$. Inclusion of

243 wheat also eliminated the $6 \%$ soybean yield lag in the tilled treatments compared

244 to zone-till observed in the SS and MS rotations (Figure 4).

245 Compared to soybean, the maize yield response to crop rotation and tillage system

246 was dependent on the year $(P<0.001$; Table 1) and variations in monthly

247 precipitation and temperature among growing seasons (Figure 2). Abnormally wet

248 and cool spring conditions in 2011 (Figure 2) delayed planting, which probably was

249 the main reason for lower maize yields and the lack of crop rotation effects in both

250 tillage treatments compared to other years (Figure 3). In 2012, abnormally dry

251 conditions and above normal temperatures during vegetative growth (Figure 1)

252 appeared to negate crop rotation effects in the tilled systems (Figure 3). However,

253 in the zone-till system, the inclusion of winter wheat increased maize yields by

$25418.8 \%$ in the dry year (Figure 3). In the two other years of the study (2010 and

255 2013), maize yielded the lowest in the MM and MS crop rotations in the tilled

256 system (Figure 3). Despite different year environments, maize response to

257 treatment did not interact with year (Table1, Figure 3). On average, winter wheat

258 improved maize performance by $16.6 \%$ and $18.8 \%$ in the zone-till and till systems,

259 respectively, and negated yield reductions due to $\mathrm{MM}$ in the zone-till system

260 (Figure 3). Our results show no significant rotation and tillage effects on wheat

261 yields, which remained stable across both treatments (Table 1). 
263 Maize yields were highly responsive to $\mathrm{N}$ fertilizer across crop rotation, but $\mathrm{N}$ 264 response interacted with crop rotation (Table 1, Figure 5A, B). In both tillage 265 systems, grain maize yield differences across rotations were the greatest at low to 266 mid- $\mathrm{N}$ rates, and increasing the $\mathrm{N}$ rate to $192 \mathrm{~kg} \mathrm{~N}$ ha-1 $^{-1}$ resulted in similar yields 267 across all crop rotations. (Figure 5A,B). Including wheat in the MS rotation 268 increased maize yields at the lowest $\mathrm{N}$ rate, while maize yields were similar at the 269 two highest rates in both tillage systems (MS vs MSW, Figure 5A,B). Similarly, 270 maize yields were higher in the MSW rotation than MM only at the two lowest rates 271 in both tillage systems (Figure $5 \mathrm{~A}, \mathrm{~B}$ ). No statistically significant maize yield gains 272 were obtained from winter wheat with red clover (MSWrc vs MS) at N rates above 273 or equal to $72 \mathrm{~kg}$ total $\mathrm{N} \mathrm{ha}^{-1}$ in zone-till (Figure $5 \mathrm{~B}$ ).

274 Increasing $\mathrm{N}$ rates did not alter rotation responses to tillage (Table 1); however, 275 tillage practice altered the magnitude of the crop rotation effects obtained at 276 various $\mathrm{N}$ rates (Figure $5 \mathrm{~A}, \mathrm{~B}$ ). Except for yield benefits obtained from the inclusion 277 of red clover into rotation, higher or similar crop rotation benefits were found at 278 lower maximum $\mathrm{N}$ rates in zone-till compared to tilled systems (Table 2). Crop 279 rotation benefits attributed to soybean (MS vs MM) were only significant in zone280 tilled systems (Figure 5, Table 2) and were maximized at $90 \mathrm{~kg} \mathrm{~N} \mathrm{ha}^{-1}(+2416 \mathrm{~kg}$ 281 ha $^{-1}$, Table 2). Similarly, maximum crop rotation benefits obtained from the 282 inclusion of soybean and wheat (MSW vs MM) were 2.1 -fold higher $(+1780 \mathrm{~kg} \mathrm{ha}-$ $283^{1}$ ) at Nmax rates which were $56 \%$ lower in zone-till compared to tilled systems 284 (Table 2). 
285 The highest yield gains $\left(+2037 \mathrm{~kg} \mathrm{ha}^{-1}\right)$ at the lowest $\operatorname{Nmax}\left(40 \mathrm{~kg} \mathrm{~N} \mathrm{ha}^{-1}\right)$ were 286 found when wheat was included into rotations of the tilled systems. The effect of

287 wheat on the crop was further enhanced when red clover was underseeded into 288 the wheat (Table 2). However, benefits from wheat, with or without red clover, 289 decreased sharply with increasing $N$ rates in zone-till systems (Figure 5B).

292 The rate of $\mathrm{N}$ that maximized grain maize yields $\left(\mathrm{Nmax}_{\mathrm{y}}\right)$ and economic returns of $293 \mathrm{~N}$ fertilization (MERN) tended to decrease with wheat in the crop rotations, 294 especially in the zone-till system (Table 3). Crop rotations including wheat and red 295 clover also reached Nmaxy and MERN values below $192 \mathrm{~kg} \mathrm{~N} \mathrm{ha}^{-1}$ in both tillage 296 systems (Table 3). Such reductions of maize $N$ requirements are likely 297 underestimates because regression models were not extrapolated beyond $192 \mathrm{~kg}$ $298 \mathrm{~N} \mathrm{ha}^{-1}$, and maximum yields were often estimated at higher $\mathrm{N}$ rates (Figure 5A, B). 299 However, grain yields at optimum $\mathrm{N}$ rates $\left(\mathrm{Y}_{\mathrm{Nmax}}\right)$ were maintained, resulting in $30017 \%$ (till) to $21 \%$ (zone-till) increase in PFPMERN associated with inclusion of wheat 301 into rotations (Table 3, MSW vs. MS). The inclusion of wheat underseeded with 302 red clover into tilled MS rotations significantly lowered $\mathrm{N}$ rates required to maximize 303 maize yields and economic returns from $\mathrm{N}$ fertilizer $(P<0.05)$ and significantly 304 increased PFPMERN (Table 3). Estimated grain maize yields obtained at zero-N 305 (intercept, $\mathrm{Y}_{\mathrm{N}=0}$ ) are function of the plant available soil $\mathrm{N}$ from net mineralization. 306 Grain yields were significantly higher when wheat, with or without red clover, was 307 included into rotations in both tillage systems (Table 3). The AE 
308 differential plant available soil N into NUE calculations and corrected for the bias 309 caused by the linear inverse correlation between MERN and $Y_{N=0}\left(R^{2}=0.81\right.$,

$310 P=0.032)$. The $A E_{M E R N}$ shows that the effects of wheat alone were likely attributed

311 to an increase in plant available soil $\mathrm{N}$, rather than an increase in efficiency of $\mathrm{N}$

312 fertilizer in both tillage systems. However, by providing a niche for red clover into

313 the crop rotation, wheat significantly increased yield obtained per unit of $\mathrm{N}$ applied

314 at MERN by $14 \mathrm{~kg}$, on average, in tilled systems (AEMERN MSW vs MSWrc, Table

315 3). Incremental $\mathrm{N}$ fertilization had the largest impact on maize yields in rotations

316 with wheat and red clover in the tilled system, especially at low $N$ rates $\left(A E_{i}\right.$, Figure

317 5C). Maize yields were less responsive to $\mathrm{N}$ fertilization when grown in rotation

318 with wheat in the zone-till system (Figure $5 \mathrm{C}$ ). The $\mathrm{AE}_{\mathrm{i}}$ showed that wheat

319 decreases fertilizer $\mathrm{N}$ requirements in maize: $\mathrm{AE}_{\mathrm{i}}$ decreased sharply with

320 increasing $\mathrm{N}$ rates when wheat was in rotation, while yields of simple rotations

321 were constrained by the maximum $\mathrm{N}$ rate applied, especially in tilled systems

322 (Figure 5C, table 3). Wheat yield responses to increasing $\mathrm{N}$ rate were not different

323 across rotation and tillage treatments (Table 1, Figure 6). Soybean yields were

324 not responsive to the long-term $\mathrm{N}$ regimes applied in previous years to maize

325 and/or wheat in the rotation (Table 1).

\section{4. Discussion}

328 The objective of this study was to quantify the long-term $\mathrm{N}$ benefits of maintaining 329 wheat in maize and soybean rotations under different tillage practices. Seven 330 maize and soybean-based rotations were grown under two tillage systems and 
331 four long-term $\mathrm{N}$ regimes in Ridgetown (ON, Canada). We show 4 years of crop

332 performance data (2010-2013) in systems established in 1995 and at, or close-to,

333 steady state across tillage, crop rotation, and N treatments. Steady state conditions

334 of soil organic matter are achieved in 15-20 years of continuous practice (West

335 and Post, 2002; Alvarez, 2005) and a meta-analysis of various long-term sites in

336 Ontario has shown that treatments established for less than 10 years provide

337 valuable insight into the long-term impact of crop production practices on soil

338 properties (Congreves et al., 2014). Our results demonstrate that the value of

339 wheat in a crop rotation with maize and soybean is much more than its market

340 price: maintaining rotation diversity in the northern Corn Belt is instrumental to

341 increase soybean productivity and maize yields using less $\mathrm{N}$ input. We found that

342 wheat: 1) produced higher maize and soybean yields in both tillage systems

343 (Figure 3,4$) ; 2$ ) acted synergistically with conservation tillage practices to reduce

344 the crop yield lag due to long-term zone-tillage (Figure 3,4) and 3) decreased

345 fertilizer $\mathrm{N}$ requirements for maximum maize yield (Figure 5, Table 3).

346 4.1. Wheat contribution to maize $N$ use efficiency

$347 \quad 4.1 .1$ Increase in plant available soil $N$

348 Wheat decreased optimal $\mathrm{N}$ fertilizer rates and PFP $\mathrm{PERN}_{\mathrm{N}}$ both directly and by 349 providing a temporal niche for underseeding red clover (Table 3).

350 In our study, wheat $\mathrm{N}$ benefits could be attributed to a higher plant available soil $\mathrm{N}$

351 rather than an increase in efficiency of $\mathrm{N}$ fertilizer used (Table 3). Mineralization of

352 wheat root biomass and stubble likely provided the $\mathrm{N}$ credit from $16 \mathrm{~kg} \mathrm{ha}^{-1}$ in the

353 tilled system to $30 \mathrm{~kg} \mathrm{ha}^{-1}$ in the zone-till system based on MERN (MS vs MSW, 
354 Table 3). Including red clover likely increased plant available soil $\mathrm{N}$ further (12 kg

$355 \mathrm{ha}^{-1}$ in zone-till, $83 \mathrm{~kg} \mathrm{ha}^{-1}$ in tilled system), and decreased maize $\mathrm{N}$ requirements

356 (Table 3). We found similar results using a compilation of maize $\mathrm{N}$ responses over

357 a range of soil type and F/P ratios for the past 40 years in Ontario (Gaudin et al.,

358 2013). It was estimated that MERN decreased by $41-64 \mathrm{~kg} \mathrm{~N} \mathrm{ha}^{-1}$ when maize

359 was preceded by red clover, with up to $7.11 \%$ positive rotational benefits of red

360 clover on maize yields in conventional tillage systems (Gaudin et al., 2013).

361 Large differences in $\mathrm{N}$ credit obtained across the tillage treatments (Table 3 ) may

362 be due to differential rates and timings of $\mathrm{N}$ release from above and below-ground

363 residues (Dou et al., 1995; Groffman et al., 1987; Sarrantonio and Scott, 1988).

364 Soil nitrate levels have been reported to be higher in conventional tillage compared

365 to zone-till throughout the growing season and incorporation of clover residue may

366 lead to higher $\mathrm{N}$ release in tilled compared to zone-till systems (Dou et al., 1995;

367 Drinkwater et al., 1998; Varco et al., 1989; Wilson and Hargrove, 1986). Moreover,

368 other studies have shown red clover to enhance wheat straw decomposition in

369 zone-till systems, which might have alleviated some of the negative effects of

370 wheat residues and zone-tillage on maize emergence and yield (Drury et al., 2003,

371 1999; Kravchenko and Thelen, 2009). However, to extract the benefits of

372 wheat/red clover on system NUE, the release of $\mathrm{N}$ from above and below-ground

373 residues must be synchronous with maize $\mathrm{N}$ uptake.

$374 \quad 4.1 .2$ Increase in N fertilizer use efficiency

375 Along with higher indigenous plant available soil $\mathrm{N}$, red clover increased the 376 efficiency of maize $\mathrm{N}$ fertilizer use $\left(A E_{M E R N}=+14 \mathrm{~kg}\right.$ grain. $\mathrm{kg} \mathrm{N}^{-1}$ applied, Table 3). 
377 This may be partially explained by maize preferably recovering $\mathrm{N}$ from fertilizer

378 instead of legume residue decomposition, as shown in several studies evaluating

$379 \mathrm{~N}$ transfer from red clover to maize using $\mathrm{N}^{15}$ isotopes (Gardner and Drinkwater, 380 2009; Harris et al., 1994).

381 Direct and indirect benefits of wheat on soil properties at this trial (Van Eerd et al.,

382 2014) may also improve recovery of $\mathrm{N}$ fertilizer. More diverse rotations and 383 improvement of soil structure, aggregation and health help foster root growth

384 (Goldstein, 2000; Nickel et al., 1995; Tisdall and Oades, 1979), which in turn may

385 improve fertilizer $\mathrm{N}$ uptake (Durieux et al., 1994; Eghball and Maranville, 1993).

386 Longer periods without tillage and abundant living plant roots in diverse rotations

387 can also host mycorrhizea over a greater duration of time within the crop rotation

388 (Brito et al., 2012; Curaqueo et al., 2010; Deguchi et al., 2007; Lehman et al., 2012;

389 Kabir, 2005). This may enhance the services they provide such as increase $\mathrm{N}$

390 uptake (George et al., 1995), especially in water-stress environments (Tobar et al., 391 1994).

392 As a result of both increase in indigenous soil $\mathrm{N}$ and higher use of $\mathrm{N}$ fertilizer,

393 maize yields were less limited by $\mathrm{N}$ supply and less responsive to $\mathrm{N}$ fertilization

394 when grown in rotation with wheat, especially in the zone-till system (Figure 5B).

395 Restrictions of $\mathrm{N}$ application due to regulation or weather constraints would have

396 a smaller impact on maize yields when grown in zone-till rotations with wheat

397 compared to MS or MM rotations. In the event of higher $\mathrm{N}$ fertilizer prices relative

398 to grain maize (i.e., higher F/P ratio), NMaxy would also be significantly reduced

399 but MEY would likely remain comparable in crop rotations with wheat. Wheat may 
400 therefore help mitigate the effects of lower $\mathrm{N}$ supply and high market volatility of $\mathrm{N}$

401 fertilizer and grain.

402 4.2. Positive feedback of lower $N$ requirements

403 We observed higher benefits of wheat and greater differences in maize yields 404 across rotations at low to mid-N rates (Table 2). Various researchers have reported

405 lower beneficial effect of crop rotation on maize yield with increasing $\mathrm{N}$ fertilization,

406 especially when legumes were included (Adams et al., 1970; Copeland and

407 Crookston, 1992; Crookston et al., 1991; Nevens and Reheul, 2001; Peterson and

408 Varvel, 1989; Porter et al., 1997; Riedell et al., 1998; Singer and Cox, 1998;

409 Stecker et al., 1995). In our study, red clover plant population densities significantly

410 decreased with increasing wheat $\mathrm{N}$ rates (from 165 plants $\mathrm{m}^{-2}$ at zero- $\mathrm{N}$ to 18

411 plants $\mathrm{m}^{-2}$ at $150 \mathrm{~kg} \mathrm{~N} \mathrm{ha}^{-1}$ across tillage systems and years, data not shown).

412 Lower rates of $\mathrm{N}$ fertilizer in wheat have been shown to increase red clover

413 biomass and stand count and decrease clover patchiness (Gaudin et al., 2014).

414 As a result, lower $\mathrm{N}$ rates maximize economic returns from wheat-red clover

415 intercropping with higher partial profits (Gaudin et al, 2014). Yet, wheat rotation

416 benefits on maize yield were masked by high $\mathrm{N}$ rates (Figure $5, \mathrm{~A}-\mathrm{B}$ ), implying that

417 higher $\mathrm{N}$ applications could offset the negative impact of monoculture or short

418 rotation. However, we show that similar yields can be obtained with lower $\mathrm{N}$ levels

419 in rotationally grown maize and that soybean yields, which were not responsive to

420 increasing $\mathrm{N}$ rates, significantly benefited from any rotation with wheat (Figures 4 ,

421 5). If $\mathrm{N}$ requirements are lower when crops are grown in rotation, the potential risk

422 of nitrate losses through leaching or denitrification may also be reduced (Varvel 
423 and Peterson, 1990; Yamoah et al., 1998b). These results highlight the value of

424 wheat as a system component and its potential to increase both maize and

425 soybean productivity using less $\mathrm{N}$ input. It also suggests that fertilizer $\mathrm{N}$ levels

426 should be taken into account when comparing crop rotation benefits across studies

427 and environments.

$428 \quad$ 4.3. Additional value of wheat on soybean yields

429 Our study also supports the hypothesis that crop productivity is increased with crop

430 rotation diversity. The inclusion of wheat in a MS or SS rotations significantly

431 increased soybean yields by an average of $0.47 \mathrm{Mg} \mathrm{ha}^{-1}$ across tillage systems

432 (Figure 4). Higher soybean yields may be attributed to the benefits of small grain

433 cereal on soil structure. Soil quality parameter such as aggregate stability,

434 penetrometer resistance and other parameters used for the Cornell Soil Health

435 Assessment, were found higher with a higher frequency of winter wheat in the

436 rotation at this trial (Van Eerd et al., 2014). Lowest soybean yields were produced

437 with continuous soybean in the tilled system (Figure 4), which corresponded with

438 the treatment with the lowest soil quality (Van Eerd et al., 2014). Others have

439 reported higher soybean yields in systems that retain soil moisture (Pedersen and

440 Lauer, 2004), which may have occurred with wheat in this study because of

441 improved soil structure. Wheat might also help break pest cycles and decrease

442 the incidence of soil-borne pathogens and soybean cyst nematodes, which can

443 negatively impact on soybean yields (Zhang et al., 2012).

444 4.4. Conclusions and significance for northern Corn Belt cropping systems

445 Crop diversity regulates various bioprocesses such as residue decomposition and 
446 microbial dynamics with large effects on nutrient cycling (McDaniel et al., 2014).

447 Given the large production areas of maize and soybean in the northern Corn Belt

448 (Figure 1), diversifying continuous or short maize and soybean rotations with wheat

449 has potential to increase NUE of agricultural systems and alleviate $\mathrm{N}$

450 environmental footprint at a large scale. However, more research and economic

451 analysis is needed to quantify opportunity costs, wheat winter survival in other

452 states of the Corn Belt and confirm potential at the Corn Belt scale. Nonetheless,

453 wheat provides a valuable temporal niche to include late-season legumes, such as

454 red clover, into northern cropping systems and obtain numerous non- $\mathrm{N}$ benefits

455 (Gaudin et al., 2013). For instance, it has been shown recently that forages, wheat

456 and other small grain cereals help mitigate weather variations and improve maize

457 and soybean yield stability in Ontario, especially when hot and dry conditions occur

458 (Gaudin et al, 2015). This is highly significant to maintain yields as springs may

459 become wetter, summers drier and hotter, with greater frequencies of abnormally

460 low precipitation or high temperature extremes (Hatfield et al., 2013; IPCC, 2013).

461 Finally, advances in crop breeding will be realized more efficiently when higher

462 crop yields are produced in diverse crop rotations, especially in the general context

463 of decreased $\mathrm{N}$ inputs and higher environmental stresses.

464

\section{5. Acknowledgements}

466 The authors gratefully thank Mr. Doug Young and Mr. Scott Jay of Ridgetown

467 Campus, University of Guelph, for establishing and maintaining the long-term 468 trials; C. Tortora for revising statistical methods as well as all the staff, students 
469 and extension specialists who have been involved with data collection and 470 interpretation. The authors also wish to acknowledge the Ontario Ministry of

471 Agriculture and Food, the Agricultural Adaptation Council, the Grain Farmers of

472 Ontario, and several seed companies for funding the long-term research trial since 4731995.

474

475 6. References

476 Adams, W., Morris, H.D., Dawson, R.N., 1970. Effect of cropping systems and

477 nitrogen levels on corn (Zea mays) yields in the southern Piedmont region. Agron.

478 J. 62, 655-659.

479 Alvarez R., 2005. A review of nitrogen fertilizer and conservation tillage effects on 480 soil organic carbon storage. Soil Use Manage. 21: 38-52

481 Brito, I., Goss, M.J., de Carvalho, M., Chatagnier, O., Van Tuinen, D., 2012. Impact 482 of tillage system on arbuscular mycorrhiza fungal communities in the soil under 483 mediterranean conditions. Soil Tillage Res. 121, 63-67.

484 Bruulsema, T.W., Christie, B.R., 1987. Nitrogen contribution to succeeding corn 485 from alfalfa and red clover. Agron. J. 79, 96-100.

486 Cassman, K.G., Dobermann, A., Walters, D.T., 2002. Agroecosystems, nitrogen487 use efficiency, and nitrogen management. AMBIO. 31, 132-140.

488 Cassman, K.G., Dobermann, A., Walters, D.T., Yang, H., 2003. Meeting cereal 489 demand while protecting natural resources and improving environmental quality.

490 Annu. Rev. Environ. Resour. 28, 315-358.

491 Congreves, K. A., Smith, J. M., Nemeth, D. D., Hooker, D. C., \& Van Eerd, L. L. 
492 (2014). Soil organic carbon and land use: Processes and potential in Ontario's 493 long-term agro-ecosystem research sites. Can. J. Soil Sci. 94, 317-336.

494 Copeland, P., Crookston, P., 1992. Crop sequence affects nutrient composition of 495 corn and soybean grown under high fertility. Agron. J. 84, 503-509.

496 Crookston, R.K., Kurle, J.E., Copeland, P.J., Ford, J.H., Lueschen, W.E., 1991.

497 Rotational cropping sequence affects yield of corn and soybean. Agron. J. 83, 108498113.

499 Culman, S.W., Snapp, S.S., Green, J.M., Gentry, L.E., 2013. Short- and long-term 500 labile soil carbon and nitrogen dynamics reflect management and predict corn 501 agronomic performance. Agron. J. 105, 493-502.

502 Curaqueo, G., Acevedo, E., Cornejo, P., Seguel, A., Rubio, R., Borie, F., 2010. 503 Tillage effect on soil organic matter, mycorrhizal hyphae and aggregates in a 504 mediterranean agroecosystem. R. C. Suelo Nutr. Veg. 10, 12-21.

505 Dapaah, H.K., Vyn, T.J., 1998. Nitrogen fertilization and cover crop effects on soil 506 structural stability and corn performance. Commun. Soil Sci. Plant Anal. 29, 25575072569.

508 Deguchi, S., Shimazaki, Y., Uozumi, S., Tawaraya, K., Kawamoto, H., Tanaka, O., 509 2007. White clover living mulch increases the yield of silage corn via arbuscular 510 mycorrhizal fungus colonization. Plant Soil. 291, 291-299.

511 Dou, Z., Fox, R., Toth, J., 1995. Seasonal soil nitrate dynamics in corn as affected 512 by tillage and nitrogen source. Soil Sci. Soc. Am. J. 59, 858-864.

513 Drinkwater, L.E., Wagoner, P., Sarrantonio, M., 1998. Legume-based cropping 514 systems have reduced carbon and nitrogen losses. Nature 396, 262-265. 
515 Drury, C.F., Tan, C.S., Welacky, T.W., Oloya, T.O., Hamill, A.S., Weaver, S.E.,

516 1999. Red clover and tillage influence on soil temperature, water content, and corn

517 emergence. Agron. J. 91, 101-108.

518 Drury, C.F., Tan, C.S., Reynolds, W.D., Welacky, T.W., Weaver, S.E., Hamill, A.S.,

519 Vyn, T.J., 2003. Impacts of zone tillage and red clover on corn performance and 520 soil physical quality. Soil Sci. Soc. Am. J. 67, 867-877.

521 Drury, C.F., Yang, X.M., Reynolds, W.D., McLaughlin, N.B., 2008. Nitrous oxide 522 and carbon dioxide emissions from monoculture and rotational cropping of corn, 523 soybean and winter wheat. Can. J. Soil Sci. 88, 163-174.

524 Durieux, R.P., Kamprath, E.J., Jackson, W.A., Moll, R.H., 1994. Root distribution 525 of corn: the effect of nitrogen fertilization. Agron. J. 86, 958-962.

526 Eghball, B., Maranville, J.W., 1993. Root development and nitrogen influx of corn 527 genotypes grown under combined drought and nitrogen stresses. Agron. J. 85, 528 147-152.

529 Gardner, J.B., Drinkwater, L.E., 2009. The fate of nitrogen in grain cropping 530 systems: a meta-analysis of $15 \mathrm{~N}$ field experiments. Ecol. Appl. 19, 2167-2184.

531 Gaudin, A.C.M., Westra, S., Loucks, C.E., Janovicek, K., Martin, R.C., Deen, W., 532 2013. Improving resilience of northern field crop systems using inter-seeded red 533 clover. Agronomy 3, 148-180.

534 Gaudin, A.C.M., Janovicek, K., Martin, R.C., Deen, W., 2014. Approaches to 535 optimizing nitrogen fertilization in a winter wheat-red clover (Trifolium pratense L.) 536 relay cropping system. F. Crop. Res. 155, 192-201.

537 Gaudin, A.C.M., Tolhurst, T., Ker, A.P., Martin, R.C., Deen, B., 2015. Increasing 
538 crop diversity mitigates weather variations and improves yield stability. PLoS ONE 539 10(2): e0113261.

540 Gentry, L.E., Snapp, S.S., Price, R.F., Gentry, L.F., 2013. Apparent red clover 541 nitrogen credit to corn: evaluating cover crop introduction. Agron. J. 105, 16585421664.

543 George, E., Marschner, H., Jakobsen, I., 1995. Role of arbuscular mycorrhizal 544 fungi in uptake of phosphorus and nitrogen from soil. Crit. Rev. Biotechnol. 15, $545 \quad 257-270$.

546 Goldstein, W.A., 2000. The effect of farming systems on the relationship of corn 547 root growth to grain yields. Am. J. Altern. Agric. 15, 101-109.

548 Groffman, P.M., Hendrix, P.F., Crossley, D.A., 1987. Nitrogen dynamics in 549 conventional and no-tillage agroecosystems with inorganic fertilizer or legume 550 nitrogen inputs. Plant Soil. 97, 315-332.

551 Grover, K.K., Karsten, H.D., Roth, G.W., 2009. Corn grain yields and yield stability 552 in four long-term cropping systems. Agron. J. 101, 940-946.

553 Harris, G., Hesterman, O.B., Paul, E.A., Peters, S.E., 1994. Fate of legume and 554 fertilizer. Agron. J. 86, 910-915.

555 Hatfield, J.L., Cruse, R.M., Tomer, M.D., 2013. Convergence of agricultural 556 intensification and climate change in the Midwestern United States: implications 557 for soil and water conservation. Mar. Freshw. Res. 64, 423-435.

558 Havlin, J., Kissel, D., Maddux, L., Claassen, M., Long, J., 1990. Crop rotation and 559 tillage effects on soil organic carbon and nitrogen. Soil Sci. Soc. Am. J. 54, 448560452. 
561 Henry, D.C., Mullen, R.W., Dygert, C.E., Diedrick, K.A., Sundermeier, A., 2010.

562 Nitrogen contribution from red clover for corn following wheat in western Ohio.

563 Agron. J. 102, 210-215.

564 Hesterman, O.B., Griffin, T.S., Williams, P.T., Harris, G.H., Christenson, D.R., 565 1992. Forage legume-small grain intercrops: nitrogen production and response of 566 subsequent Corn. J. Prod. Agric. 5, 340-348.

567 IPCC., 2013. Climate Change 2013: The Physical Science Basis. Contribution of

568 Working Group I to the Fifth Assessment Report of the Intergovernmental Panel

569 on Climate Change. Cambridge University Press, Cambridge, United Kingdom.

570 Katsvairo, T., Cox, W.J., Van Es, H., 2002. Tillage and rotation effects on soil 571 physical characteristics. Agron. J. 94, 121-125.

572 Katsvairo, T.W., Cox, W.J., 2000. Tillage $\mathrm{x}$ rotation $\mathrm{x}$ management interactions in 573 corn. Agron. J. 92, 493-500.

574 Kravchenko, A., Thelen, K.D., 2009. Clover and manure management strategies 575 for overcoming the wheat residue antagonism of no-till corn. J. Sustain. Agric. 33, $576 \quad 491-511$.

577 Langdale, G.W., Blevins, R.L., Karlen, D.L., McCool, D.K., Nearing, M.A., 578 Skidmore, E.L., Thomas, A.W., Tyler, D.D., Williams, J.R., 1991. Cover crop 579 effects on soil erosion by wind and Water, in: Hargrove, W.L. (Ed.), Cover Crops 580 for Clean Water. Soil Water and Conservation Society, pp. 15-22.

581 Lebender, U., Senbayram, M., Lammel, J., Kuhlmann, H., 2014. Effect of mineral 582 nitrogen fertilizer forms on $\mathrm{N} 2 \mathrm{O}$ emissions from arable soils in winter wheat 583 production. J. Soil Sci. Plant Nutr. 177, 722-732 
584 Lehman, R.M., Taheri, W.I., Osborne, S.L., Buyer, J.S., Douds, D.D., 2012. Fall 585 cover cropping can increase arbuscular mycorrhizae in soils supporting intensive 586 agricultural production. Appl. Soil Ecol. 61, 300-304.

587 Liebig, M., Morgan, J., Reeder, J., Ellert, B., Gollany, H., Schuman, G., 2005. 588 Greenhouse gas contributions and mitigation potential of agricultural practices in 589 northwestern USA and western Canada. Soil Tillage Res. 83, 25-52.

590 Liebman, M., Graef, R., Nettleton, D., CA Cambardella, 2012. Use of legume green 591 manures as nitrogen sources for corn production. Renew. Agric. Food Syst. 27, $592 \quad 180-191$.

593 Liebman, M., Helmers, M.J., Schulte-Moore, L.A., Chase, C.A., 2013. Using 594 biodiversity to link agricultural productivity with environmental quality: results from 595 three field experiments in lowa. Renew. Agric. Food Syst. 28, 115-128.

596 Lund, M.G., Carter, P.R., Oplinger, E.S., 1993. Tillage and crop rotation affect 597 corn, soybean and winter wheat yields. J. prod. Agric. 6, 143-213.

598 McDaniel, M.D., Tiemann, L., Grandy, A., 2014. Does agricultural crop diversity 599 enhance soil microbial biomass and organic matter dynamics? A meta-analysis. 600 Ecol. Appl. 24, 560-70.

601 McDaniel, M.D., Grandy, A.S., Tiemann, L.K., Weintraub, M.N., 2014. Crop 602 rotation complexity regulates the decomposition of high and low quality residues. 603 Soil Biol. Biochem. 78, 243-254.

604 Meyer-Aurich, A., Weersink, A., Janovicek, K., Deen, B., 2006. Cost efficient 605 rotation and tillage options to sequester carbon and mitigate GHG emissions from 606 agriculture in eastern Canada. Agric. Ecosyst. Environ. 117, 119-127. 
607 Meyer-Aurich, A., Janovicek, K., Deen, W., Weersink, A., 2006. Impact of tillage 608 and rotation on yield and economic performance in corn-based cropping systems. 609 Agron. J. 98, 1204-1212.

610 Munkholm, L.J., Heck, R.J., Deen, B., 2013. Long-term rotation and tillage effects 611 on soil structure and crop yield. Soil Tillage Res. 127, 85-91.

612 Nevens, F., Reheul, D., 2001. Crop rotation versus monoculture; yield, N yield and 613 ear fraction of silage maize at different levels of mineral $\mathrm{N}$ fertilization. Neth. J. Agr. 614 Sci. 49, 405-425.

615 Nickel, S.E., Crookston, R.K., Russelle, M.P., 1995. Root growth and distribution

616 are affected by corn-soybean cropping sequence. Agron. J. 87, 895-902.

617 Nickerson, C., Ebel, R., Borchers, A., Carriazo, F., 2007. Major uses of land in the 618 United States.

619 OMAFRA, 2014. Ontario Ministry of Agriculture, Food and rural Affairs, Field 620 crops statistics. Accessed 10/01/2014.

621 (http://www.omafra.gov.on.ca/english/stats/crops/).

622 Pedersen, P., Lauer, J.G., 2004. Soybean growth and development response to 623 rotation sequence and tillage system. Agron. J. 96, 1005-1012.

624 Peoples, M.B., Boyer, E.W., Goulding, K.W.T, Heffer, P., Ochwoh, V.A., Vanlauwe, 625 B., Wood, S., Yagi, K., Van Cleemput, O., 2004. Pathways of nitrogen loss and 626 their impact on human health and the environment, in: Mosier, A.R., Syers, J.K., 627 Freney, J.R. (Eds.), Agriculture and the Nitrogen Cycle: Assessing the Impacts of 628 Fertilizer Use on Food Production and the Environment. Island Press, pp. 53-71. 629 Peterson, T.A., Varvel, G.E., 1989. Crop yield as affected by rotation and nitrogen 
630 rate. III. Corn. Agron. J. 81, 735-738.

631 Porter, P.M., Crookston, R.K., Ford, J.H., Huggins, D.R., Lueschen, W.E., 1997.

632 Interrupting yield depression in monoculture corn: comparative effectiveness of 633 grasses and dicots. Agron. J. 89, 247-250.

634 Rachman, A., Anderson, S.H., Gantzer, C.J., Thompson, A.L., 2003. Influence of 635 long-term cropping systems on soil physical properties related to soil erodibility. 636 Soil Sci. Soc. Am. J. 67, 637-644.

637 Raimbault, B.A., Vyn, T.J., 1991. Crop rotation and tillage effects on corn growth 638 and soil structural stability. Agron. J. 985, 979-985.

639 Rajsic, P., Weersink, A., 2008. Do farmers waste fertilizer? A comparison of ex 640 post optimal nitrogen rates and ex ante recommendations by model, site and year. 641 Agric. Syst. 97, 56-67.

642 Riedell, W.E., Schumacher, T.E., Clay, S.A., Ellsbury, M.M., Pravecek, M., 643 Evenson, P.D., 1998. Corn and soil fertility responses to crop rotation with low, 644 medium, or high inputs. Crop Sci. 38, 427-433.

645 Sarrantonio, M., Scott, T., 1988. Tillage effects on availability of nitrogen to corn 646 following a winter green manure crop. Soil Sci. Soc. Am. J. 52, 1661-1668.

647 Shipitalo, M.J., Owens, L.B., Bonta, J. V., Edwards, W.M., 2013. Effect of no-till 648 and extended rotation on nutrient losses in surface runoff. Soil Sci. Soc. Am. J. 77, $649 \quad 1329-1337$.

650 Singer, J., Cox, W.J., 1998. Corn growth and yield under different crop rotation, 651 tillage, and management systems. Crop Sci. 38, 996-1003.

652 Smith, R.G., Gross, K.L., Robertson, G.P., 2008. Effects of crop diversity on 
653 agroecosystem function: crop yield response. Ecosystems 11, 355-366.

654 Stanger, T.F., Lauer, J.G., 2008. Corn grain yield response to crop rotation and

655 nitrogen over 35 years. Agron. J. 100, 643-650.

656 Stecker, J.A., Buchholz, D.D., Hanson, R.G., Wollenhaupt, N.C., McVay, K.A., 657 1995. Tillage and rotation effects on corn yield response to fertilizer nitrogen on 658 Aqualf Soils. Agron. J. 87, 409-415.

659 Stute, J.K., Posner, J.L., 1995. Synchrony between legume nitrogen release and 660 corn demand in the upper Midwest. Agron. J. 87, 1063-1069.

661 Syswerda, S.P., Basso, B., Hamilton, S.K., Tausig, J.B., Robertson, G.P., 2012.

662 Long-term nitrate loss along an agricultural intensity gradient in the Upper Midwest 663 USA. Agric Ecosyst Environ.149, 10-19.

664 Tisdall, J., Oades, J., 1979. Stabilization of soil aggregates by the root systems of 665 ryegrass. Aust. J. Soil Res. 17, 429-441.

666 Tisdall, J.M., Oades, J.M., 1982. Organic matter and water-stable aggregates in 667 soils. J. Soil Sci. 33, 141-163.

668 Tobar, R.M., Azcon, R., Barea, J.M., 1994. The improvement of plant N acquisition 669 from an ammonium-treated, drought-stressed soil by the fungal symbiont in 670 arbuscular mycorrhizae. Mycorrhiza 4, 105-108.

671 USDA-NASS., 2014a. United States Department of Agriculture, National 672 Agricultural Statistics Service. Agricultural Prices, Accessed 09/24/2014. 673 (http://www.ers.usda.gov/data-products/fertilizer-use-and-price.aspx\#26727).

674 USDA-NASS., 2014b. United States Department of Agriculture, National 675 Agriculture Statistics Service database. Accessed 09/26/2014. 
676 (http://www.nass.usda.gov/Statistics_by_Subject/index.php?sector=CROPS)

677 Van Eerd, L.L., Congreves, K.A., Hayes, A., Verhallen, A., Hooker, D., 2014. Long-

678 term tillage and crop rotation effects on soil quality, organic carbon, and total 679 nitrogen. Can. J. Soil Sci. 94, 303-315.

680 Varco, J., Frye, W., Smith, M., MacKown, C., 1989. Tillage effects on nitrogen 681 recovery by corn from a nitrogen-15 labeled legume cover crop. Soil Sci. Soc. Am. 682 J. 53, 822-827.

683 Varvel, G.E., 1994. Rotation and nitrogen fertilization effects on changes in soil 684 carbon and nitrogen. Agron. J. 86, 319-325.

685 Varvel, G.E., 2000. Crop rotation and nitrogen effects on normalized grain yields 686 in a long-term study. Agron. J. 92, 938-941.

687 Varvel, G.E., Peterson, T.A., 1990. Residual soil nitrogen as affected by 688 continuous, two-year, and four-year crop rotation systems. Agron. J. 82, 958-962. 689 Vyn, T.J., Faber, J.G., Janovicek, K.J., Beauchamp, E.G., 2000. Cover crop effects 690 on nitrogen availability to corn following wheat. Agron. J. 92, 915-924.

691 Vyn, T.J., Hooker, D.C., 2002. Assessment of multiple- and single-factor stress 692 impacts on corn. F. Crop. Res. 75, 123-137.

693 West, T.O., Post, W.M. (2002). Soil organic carbon sequestration rates by tillage 694 and crop rotation. Soil Science Society of America Journal, 66, 1930-1946.

695 Wilson, D., Hargrove, W., 1986. Release of nitrogen from crimson clover residue 696 under two tillage systems. Soil Sci. Soc. Am. J. 50, 1251-1254.

697 Wivstad, M., 1999. Nitrogen mineralization and crop uptake of $\mathrm{N}$ from 698 decomposing $15 \mathrm{~N}$ labelled red clover and yellow sweetclover plant fractions of 
699 different age. Plant Soil 208, 21-31.

700 Wright, C.K., Wimberly, M.C., 2013. Recent land use change in the western Corn

701 Belt threatens grasslands and wetlands. Proc. Natl. Acad. Sci. U.S.A. 110, 41347024139.

703 Yamoah, C.F., Francis, C.A., Varvel, G.E., Waltman, W.J., 1998a. Weather and

704 management impact on crop yield variability in rotations. J. Prod. Agric. 2, 219705225.

706 Yamoah, C.F., Varvel, G.E., Waltman, W.J., Francis, C.A., 1998b. Long-term 707 nitrogen use and nitrogen-removal index in continuous crops and rotations. F. 708 Crop. Res. 57, 15-27.

709 Zhang, Q.Y., Li, Z.L., Han, B.J., Zhoa, K.Q., Zhang, X.Y., Hashemi, M., Liu, X.B., 710 2012. Immediate responses of cyst nematode, soil-borne pathogens and soybean

711 yield to one-season crop disturbance after continuous soybean in northeast China.

712 Int. J. Plant Prod. 7, 341-354.

713

714

715 7. Figure legend

716 Figure 1. Harvested areas of field crops grown in four states/provinces of the

717 northern Corn Belt from 1981-2013. Harvested areas (hectares) of major field

718 crops are shown as \% of total harvested area from 1981- 2013 for Ontario (

719 OMAFRA, 2014), Michigan, Minnesota and lowa (USDA-NASS, 2014b). Surface

720 areas harvested in canola and hay were not included for clarity.

721 Figure 2. Weather conditions at the experimental site. (A) Monthly 10-year 
722 average temperature (bars) and precipitation (line) pattern (2003-2013). Mean

723 temperature (A) and total precipitation (B) deviation from 10-year average during

724 crop growth (March to November) for each study year (2010-2013). Weather data

725 was collected daily by Environment Canada at the site.

726 Figure 3. Yearly variation in maize yields response to rotation and tillage. LS

727 means \pm SE across $N$ treatment are shown. Letters indicate statistical differences

728 among rotations within tillage treatment for each year and $\left(^{*}\right)$ indicate significant

729 tillage effect for each rotation at $p=0.05$. Crop abbreviation: $S=$ soybean, $M=$ maize,

$730 \mathrm{~W}=$ winter wheat, $\mathrm{Wrc}=$ winter wheat underseeded with red clover.

731 Figure 4. Soybean yields response to rotation and tillage. LS means (2010-

732 2013) \pm SE across $N$ treatment are shown. Letters indicate statistical differences

733 among rotations within tillage treatment and $\left({ }^{*}\right)$ indicate significant tillage effect for

734 each rotation at $p=0.05$. Crop abbreviation: $S=$ soybean, $M=$ maize, $W=$ winter

735 wheat, $\mathrm{Wrc}=$ winter wheat underseeded with red clover.

736 Figure 5. Impact of crop rotation and tillage on maize yields response to $\mathbf{N}$

737 fertilization. Regression analysis of the effects of $\mathrm{N}$ rate treatments on maize

738 yields under (A) conventional tillage and (B) zone tillage systems. Maize yield

739 response to $\mathrm{N}$ rates (2010-2013) was fitted using quadratic plateau models capped

740 at $192 \mathrm{~kg} \mathrm{~N} \mathrm{ha}^{-1}$. Nitrogen rates maximizing yields for each rotation and tillage

741 treatments are presented in Table 3. Markers show treatment LS means used for

742 regression analysis \pm SE. (C) Agronomic efficiency of $N$ fertilization $\left(A E_{i}\right)$.

743 Agronomic efficiencies are estimated yield gain per unit of increasing $\mathrm{N}$ fertilization

744 based on $\mathrm{N}$ response equations (A-B). Crop abbreviation: $\mathrm{S}=$ soybean, $\mathrm{M}=$ maize, 
$745 \mathrm{~W}=$ winter wheat, $\mathrm{Wrc}=$ winter wheat underseeded with red clover.

746 Figure 6. Impact of crop rotation and tillage on wheat yields response to $\mathbf{N}$

747 fertilization. (A-B) Regression analysis of the effects of $\mathrm{N}$ rate treatments on

748 wheat yields (2010-2013) under (A) conventional tillage and (B) zone tillage

749 systems. Wheat yield response to $\mathrm{N}$ rates was fitted using quadratic plateau

750 models capped at $150 \mathrm{~kg} \mathrm{~N} \mathrm{ha}^{-1}$. Markers show treatment LS means used for

751 regression analysis \pm SE. Crop abbreviation: $S=$ soybean, $M=$ maize, $W=$ winter

752 wheat, $\mathrm{Wrc}=$ winter wheat underseeded with red clover.

753 Figure A.1. Changes in crop-specific rotation benefits with $\mathbf{N}$ fertilization. (A-

754 B) Regression analysis of the effects of $\mathrm{N}$ rate treatments on maize yield benefits

755 associated with different crops under (A) conventional tillage and (B) zone tillage

756 systems. Maize yield response to $\mathrm{N}$ rates was fitted using quadratic plateau

757 models capped at 0 and $192 \mathrm{~kg} \mathrm{~N} \mathrm{ha}^{-1}$. Regression models and $\mathrm{N}$ rates maximizing

758 yield benefits for each crop are presented in Table 2. Crop abbreviation: $\mathrm{S}=$

759 soybean, $M=$ maize, $\mathrm{W}=$ winter wheat, $\mathrm{WrC}=$ winter wheat underseeded with red 760 clover.

761

762 
$\square$ Rye $\square$ Beans $\square$ Oats $\square$ Spring wheat $\square$ Barley $\square$ Winter wheat $E$ Maize (grain + fodder) $\$$ Soybean Ontario Michigan

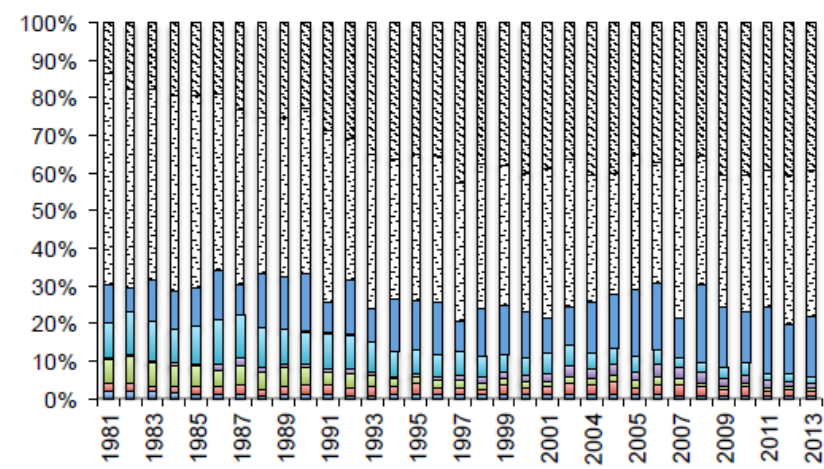

Minnesota
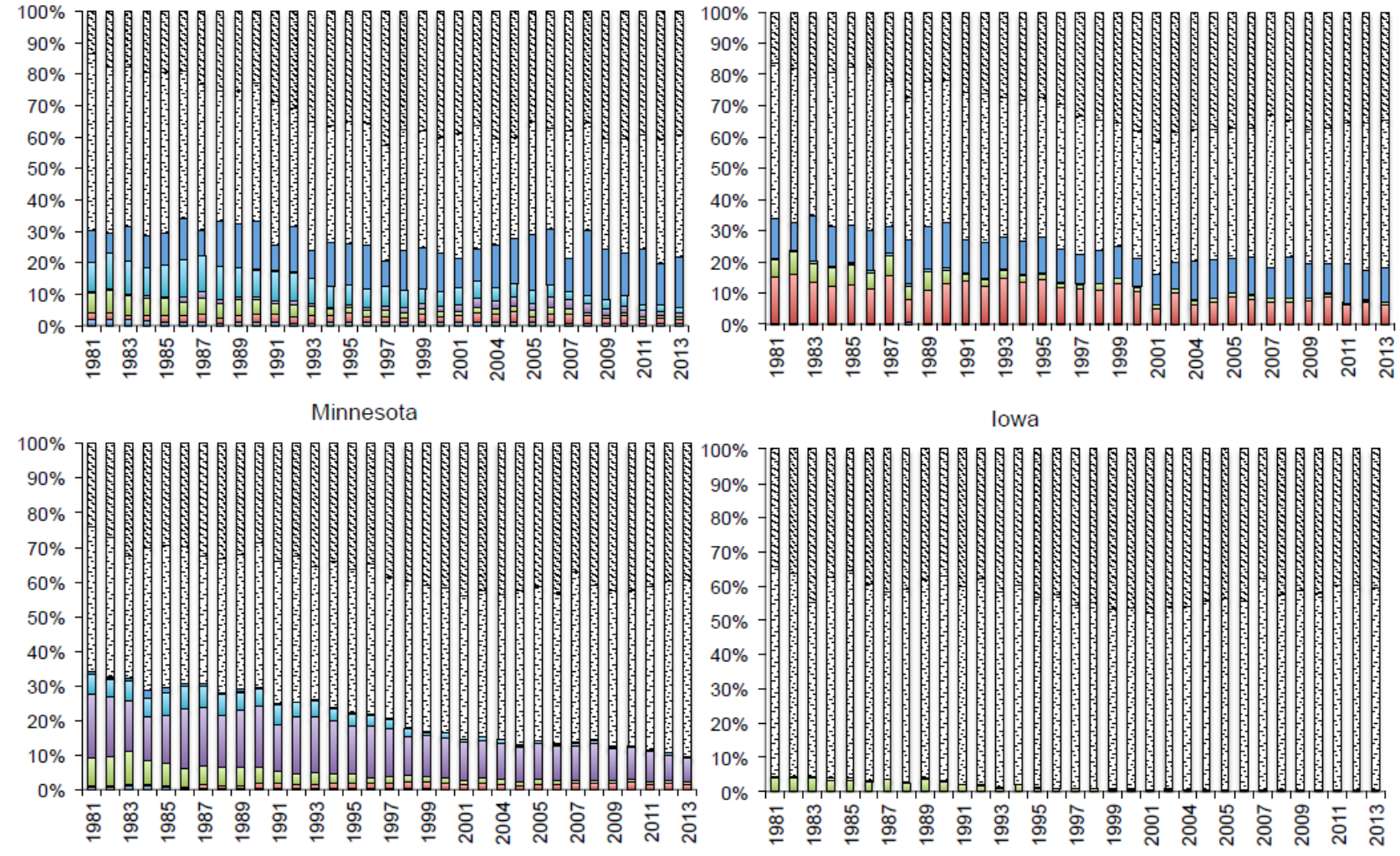

lowa

763

\section{$764 \quad$ Fig 1}

765 


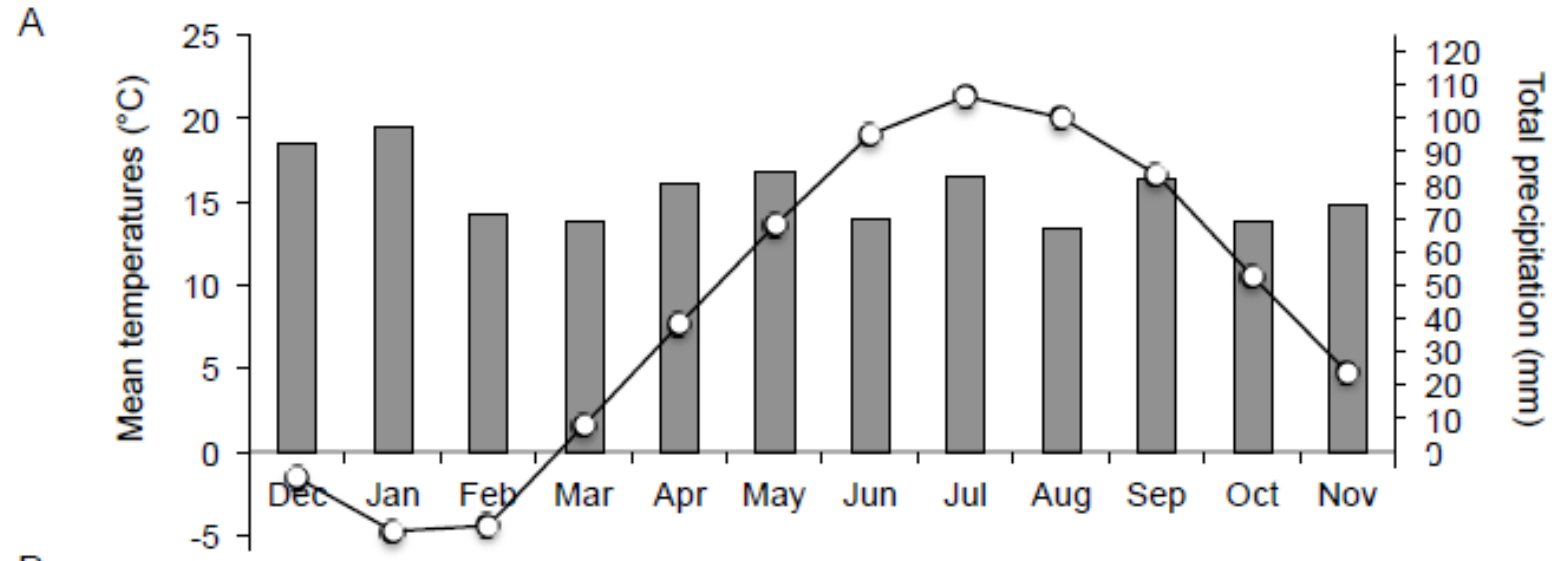

B

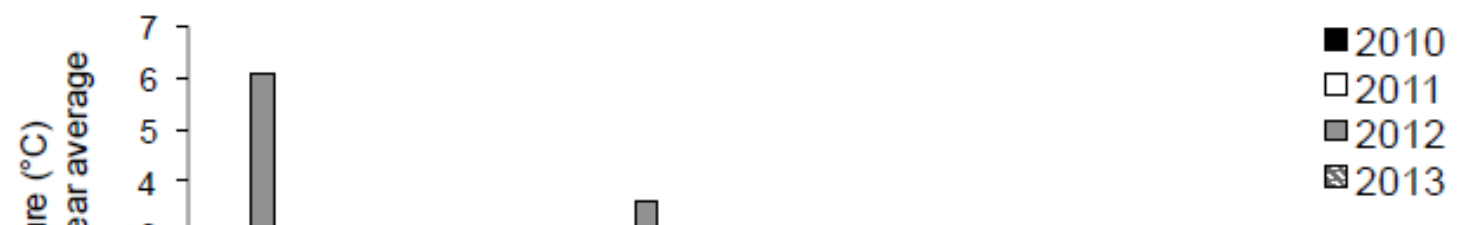

C 100$]^{\text {Mar Apr May Jun Jul Aug Sep Oct Nov }}$



766

$767 \quad$ Fig 2

768 


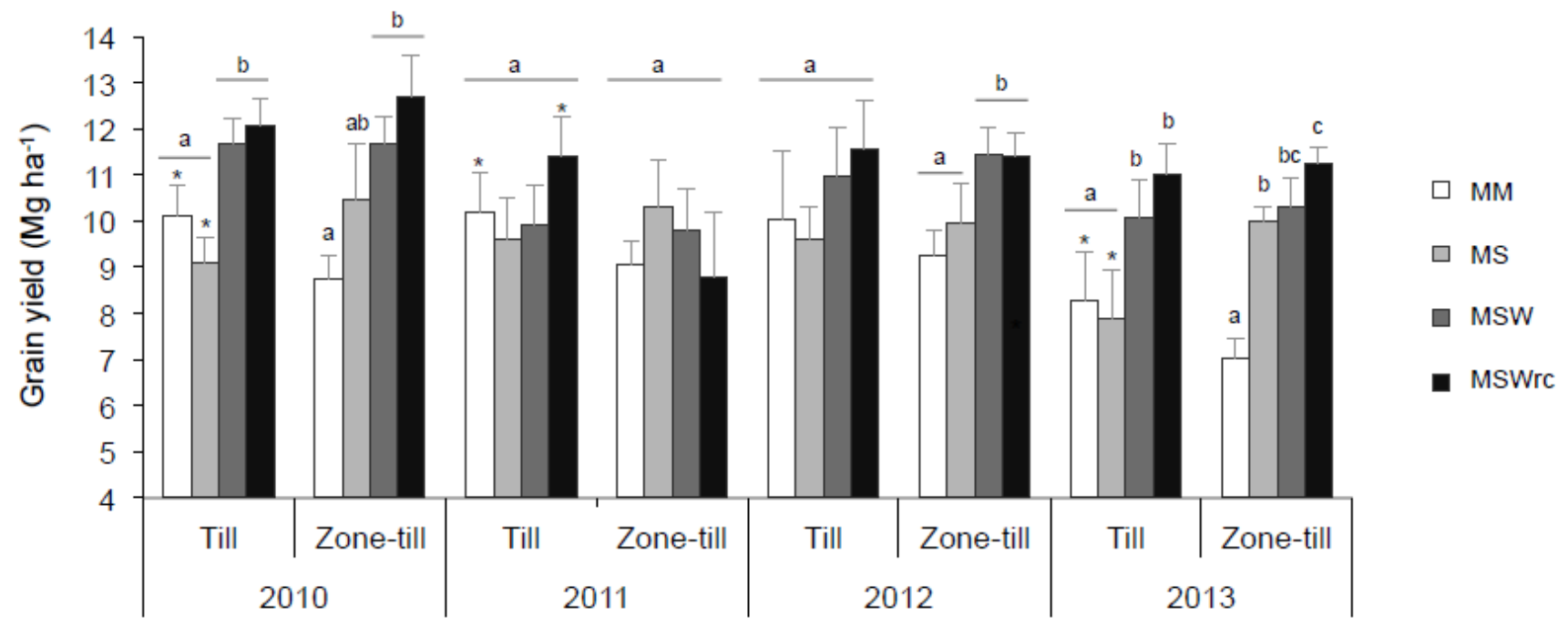

769

$770 \quad$ Fig 3

771

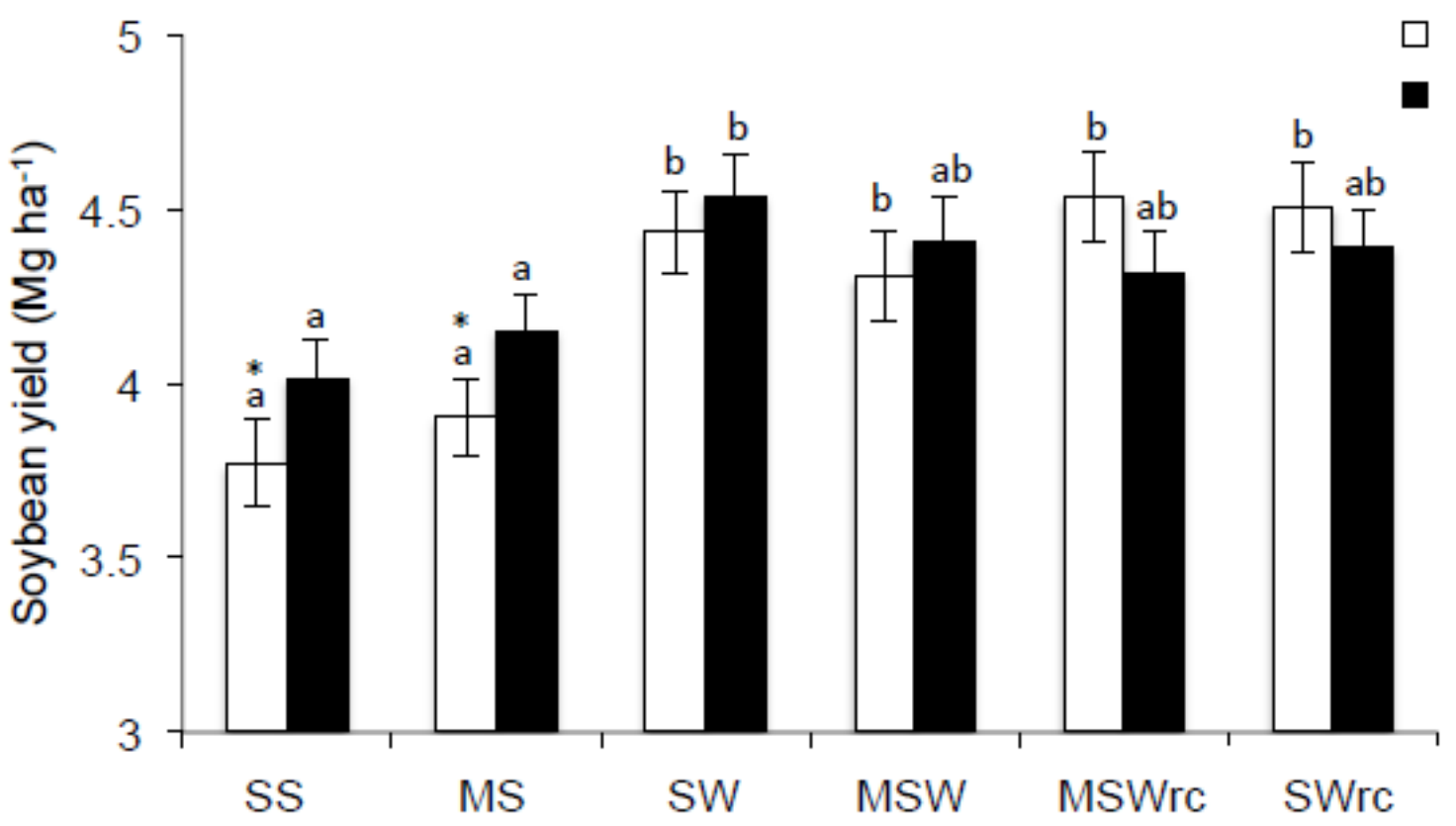

Fig 4 
A

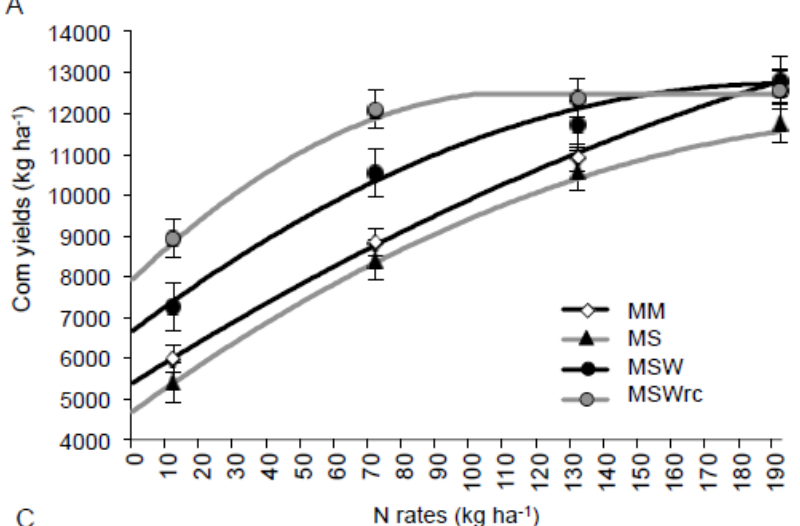

C



776 $\mathrm{N}$ rates $\left(\mathrm{kg} \cdot \mathrm{ha}^{-1}\right)$



\section{$777 \quad$ Fig 5}

\section{8}

A

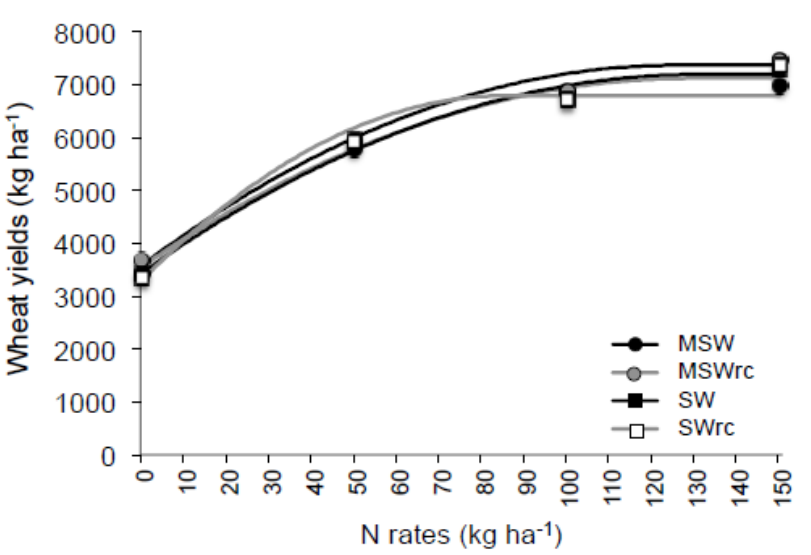

B

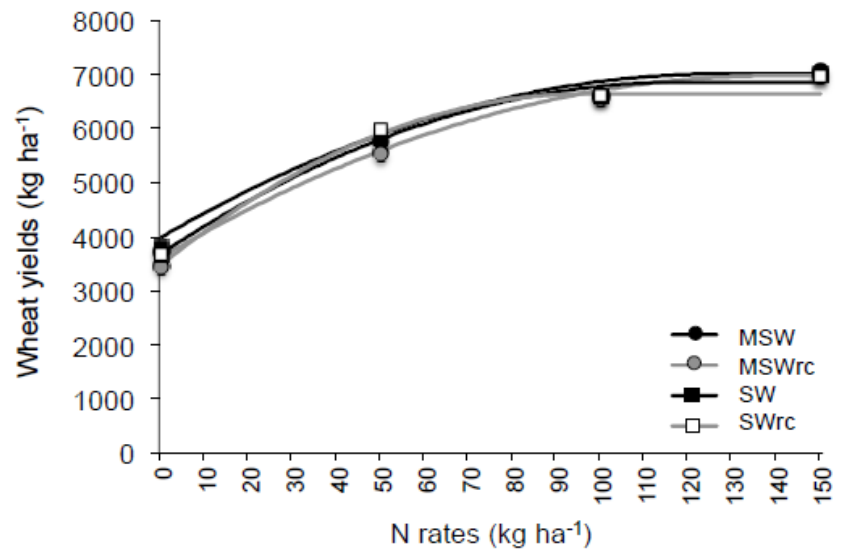

\section{$780 \quad$ Fig 6}



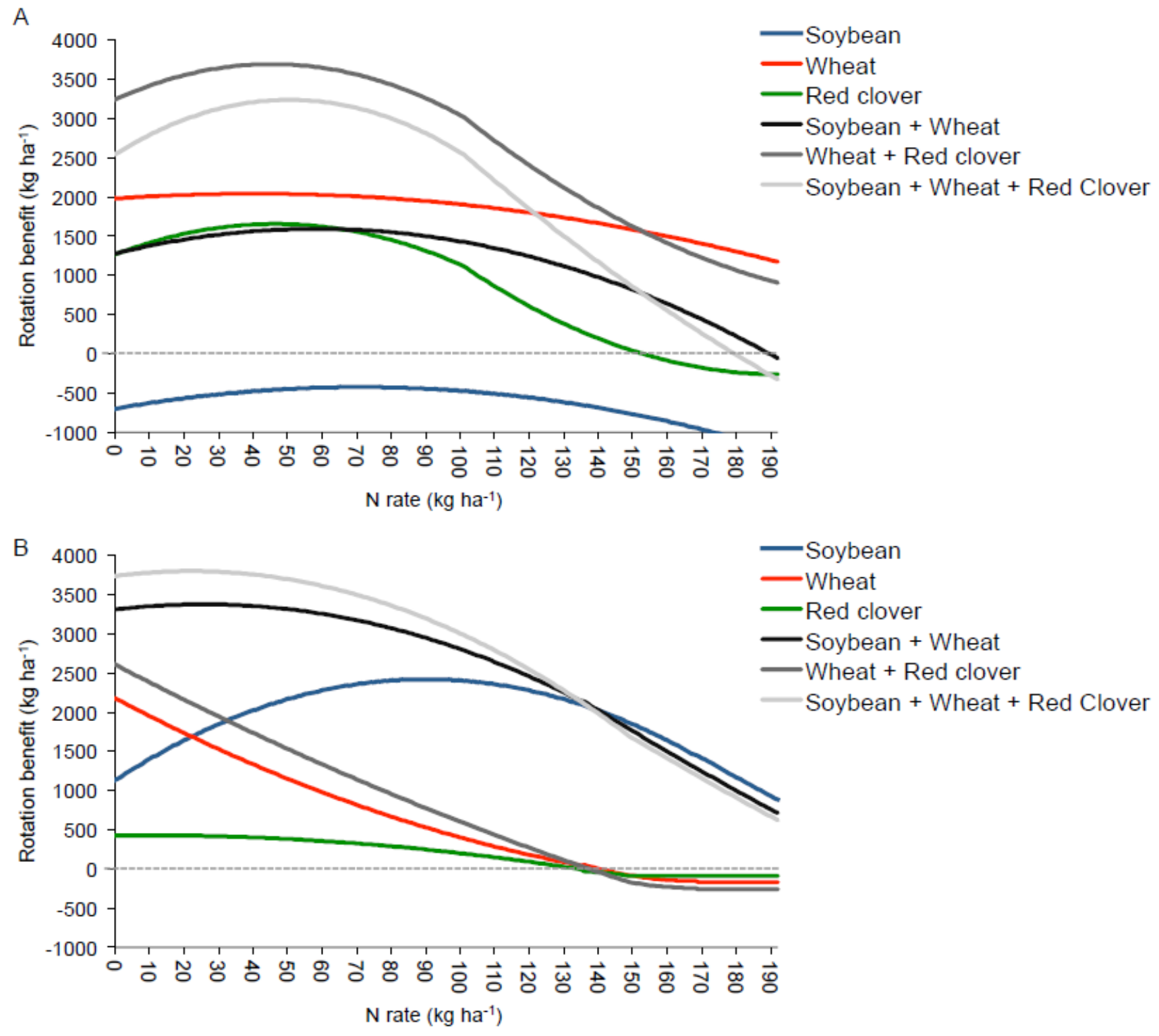

\section{$783 \quad$ Fig A1}


Table 1. Long term rotation, tillage and nitrogen effects on maize, soybean and wheat yields grown from $2010-2013$.

\begin{tabular}{|c|c|c|c|c|c|c|c|c|c|c|}
\hline \multirow{3}{*}{ Year } & & \multicolumn{3}{|c|}{ Maize yield } & \multicolumn{3}{|c|}{ Soybean yield } & \multicolumn{3}{|c|}{ Wheat yield } \\
\hline & & \multirow{2}{*}{$\begin{array}{l}d f \\
3\end{array}$} & \multicolumn{2}{|l|}{$\operatorname{Pr}(>\mathrm{F})$} & \multirow{2}{*}{$\frac{d f}{2}$} & \multicolumn{2}{|l|}{$\operatorname{Pr}(>\mathrm{F})$} & \multirow{2}{*}{$\frac{d f}{1}$} & \multicolumn{2}{|l|}{$\operatorname{Pr}(>\mathrm{F})$} \\
\hline & & & $<0.001$ & ** & & $<0.001$ & ** & & 0.021 & * \\
\hline \multicolumn{2}{|l|}{ Tillage } & 1 & 0.801 & & 1 & 0.713 & & 1 & 0.286 & \\
\hline \multicolumn{2}{|c|}{ Rotation } & 3 & $<0.001$ & ** & 5 & $<0.001$ & ** & 3 & 0.090 & \\
\hline \multicolumn{2}{|c|}{ Nitrogen ${ }^{\square a}$} & 3 & $<0.001$ & $* *$ & 3 & 0.477 & & 3 & $<0.001$ & ** \\
\hline \multicolumn{2}{|c|}{ Year x Tillage } & 3 & 0.044 & * & 2 & 0.079 & & 1 & 0.773 & \\
\hline \multicolumn{2}{|c|}{ Year x Rotation } & 9 & $<0.001$ & ** & 10 & 0.004 & * & 3 & $<0.001$ & ** \\
\hline \multicolumn{2}{|c|}{ Year x Nitrogen } & 9 & $<0.001$ & ** & 6 & 0.068 & & 3 & $<0.001$ & ** \\
\hline \multicolumn{2}{|c|}{ Tillage x Rotation } & 3 & 0.016 & * & 5 & 0.008 & * & 3 & 0.731 & \\
\hline \multicolumn{2}{|c|}{ Rotation x Nitrogen } & 9 & $<0.001$ & ** & 15 & 0.387 & & 9 & 0.555 & \\
\hline \multicolumn{2}{|c|}{ Nitrogen x Tillage } & 3 & $<0.001$ & ** & 3 & 0.345 & & 3 & 0.071 & \\
\hline \multicolumn{2}{|c|}{ Year x Tillage x Rotation } & 9 & 0.105 & & 10 & 0.539 & & 3 & 0.184 & \\
\hline \multicolumn{2}{|c|}{ Year x Rotation x Nitrogen } & 27 & 0.301 & & 30 & 0.614 & & 9 & 0.324 & \\
\hline \multicolumn{2}{|c|}{ Year x Nitrogen x Tillage } & 9 & 0.119 & & 6 & 0.499 & & 3 & 0.278 & \\
\hline \multicolumn{2}{|c|}{ Tillage $x$ Nitrogen $x$ Rotation } & 9 & 0.535 & & 15 & 0.338 & & 9 & 0.594 & \\
\hline \multirow[t]{4}{*}{ Maize: } & $0 \mathrm{~kg} \mathrm{~N} \mathrm{ha}^{-1}$ & 7 & $<0.001$ & ** & & $\mathrm{N} / \mathrm{A}$ & & & $\mathrm{N} / \mathrm{A}$ & \\
\hline & $72 \mathrm{~kg} \mathrm{~N} \mathrm{ha-1}$ & 7 & $<0.001$ & ** & & $\mathrm{N} / \mathrm{A}$ & & & $N / A$ & \\
\hline & $132 \mathrm{~kg} \mathrm{~N} \mathrm{ha}^{-1}$ & 7 & $<0.001$ & ** & & $N / A$ & & & $\mathrm{~N} / \mathrm{A}$ & \\
\hline & $192 \mathrm{~kg} \mathrm{~N} \mathrm{ha}^{-1}$ & 7 & 0.089 & & & $\mathrm{~N} / \mathrm{A}$ & & & $N / A$ & \\
\hline \multirow[t]{4}{*}{ Wheat: } & $0 \mathrm{~kg} \mathrm{~N} \mathrm{ha}^{-1}$ & & $\mathrm{~N} / \mathrm{A}$ & & & $\mathrm{N} / \mathrm{A}$ & & 7 & 0.830 & \\
\hline & $50 \mathrm{~kg} \mathrm{~N} \mathrm{ha}^{-1}$ & & $\mathrm{~N} / \mathrm{A}$ & & & $N / A$ & & 7 & 0.112 & \\
\hline & 100 kg N ha-1 & & $N / A$ & & & $N / A$ & & 7 & 0.582 & \\
\hline & $150 \mathrm{~kg} \mathrm{~N} \mathrm{ha}^{-1}$ & & $\mathrm{~N} / \mathrm{A}$ & & & $N / A$ & & 7 & 0.124 & \\
\hline \multicolumn{3}{|c|}{ Year $x$ Tillage $x$ Rotation $x$ Nitroge } & 0.528 & & 30 & 0.522 & & 9 & 0.209 & \\
\hline
\end{tabular}

786 (a) Nitrogen rates directly applied to maize and wheat or as part of the rotation history for soybean.

$787\left({ }^{*}\right)$ Significant at 0.05 probability level, $\left({ }^{* *}\right)$ Significant at $<0.001$ probability level, (N/A) Non applicable 
788 Table 2. Effects of $\mathrm{N}$ fertilization on crop-specific rotational benefits to maize yields

\begin{tabular}{llllllll} 
& & $\begin{array}{l}\text { Nmax } \\
\left(\mathrm{kg} \mathrm{N} \mathrm{ha}^{-1}\right)\end{array}$ & \multicolumn{2}{l}{$\begin{array}{l}\mathrm{Y}_{\mathrm{r}} \text { at Nmax } \\
\left(\mathrm{kg} \mathrm{ha}^{-1}\right)\end{array}$} & $\begin{array}{l}\text { Regression models } \\
(\text { Capped at 0 and 192 kg N ha }\end{array}$ \\
\cline { 3 - 8 } Rotation benefits
\end{tabular}

790

791 Nitrogen rates maximizing rotation effect $\left(\mathrm{Nmax}_{\mathrm{r}}\right)$ were calculated based on the regression models. Corresponding 792 regression curves are shown in Figure A.3. Abbreviations: $Y_{r}=$ Yield gain from rotation crops; $S=$ soybean, $M=m a i z e$, 793 W=winter wheat, Wrc $=$ winter wheat underseeded with red clover. 
Table 3. Effect of crop rotation on maize $\mathrm{N}$ use and economic optimums

796

\begin{tabular}{|c|c|c|c|c|c|c|c|c|c|c|c|c|c|c|}
\hline \multirow[b]{2}{*}{ Rotation } & \multicolumn{2}{|c|}{$\begin{array}{l}\text { Nmaxy } \\
\left(\mathrm{kg} \mathrm{N} \mathrm{ha}{ }^{-1}\right)\end{array}$} & \multicolumn{2}{|l|}{$\begin{array}{l}Y_{\mathrm{Nmax}} \\
\left(\mathrm{kg} \mathrm{ha}^{-1}\right)\end{array}$} & \multicolumn{2}{|c|}{$\begin{array}{l}\text { MERN } \\
\left(\mathrm{kg} \mathrm{N} \mathrm{ha}^{-1}\right)\end{array}$} & \multicolumn{2}{|l|}{$\begin{array}{l}\text { MEY } \\
\left(\mathrm{kg} \mathrm{ha}^{-1}\right)\end{array}$} & \multicolumn{2}{|c|}{$\begin{array}{l}\text { PFP }_{\text {MERN }} \\
\left(\mathrm{kg}_{\text {grain }} \mathrm{kg} \mathrm{N}^{-1}\right)\end{array}$} & \multicolumn{2}{|c|}{$\begin{array}{l}Y_{\mathrm{N}=0} \\
\left(\mathrm{~kg} \mathrm{ha} \mathrm{h}^{-1}\right)\end{array}$} & \multicolumn{2}{|c|}{$\begin{array}{l}\text { AE MERN } \\
\left(\mathrm{kg}_{\mathrm{M}} \text { grain } \mathrm{kg}\right. \\
\left.\mathrm{N}^{-1}\right)\end{array}$} \\
\hline & Till & $\begin{array}{c}\text { Zone } \\
\text { Till }\end{array}$ & Till & $\begin{array}{c}\text { Zone } \\
\text { Till }\end{array}$ & Till & $\begin{array}{c}\text { Zone } \\
\text { Till }\end{array}$ & Till & $\begin{array}{c}\text { Zone } \\
\text { Till }\end{array}$ & Till & $\begin{array}{c}\text { Zone } \\
\text { Till }\end{array}$ & Till & $\begin{array}{c}\text { Zone } \\
\text { Till }\end{array}$ & Till & $\begin{array}{c}\text { Zone } \\
\text { Till }\end{array}$ \\
\hline MM & $192^{a}$ & 192 & 12730 * & 11039 & $192^{a}$ & $192^{a}$ & 12730 * & 11039 & 66 & 57 & $5386^{a}$ & $5299^{a}$ & 38 & 30 \\
\hline MS & $192^{a}$ & 174 & 11786 & 11920 & $192^{a}$ & $154^{a}$ & 11786 & 11853 & 61 & 77 & $4684^{a}$ & $6427^{b}$ & 37 & 35 \\
\hline MSW & $192^{a}$ & 150 & 12710 & 11660 & $1766^{a b}$ & $124^{a b}$ & 12638 & 11570 & 72 & 93 & $6661^{b}$ & $8603^{c}$ & 34 & 24 \\
\hline MSWrc & $101^{b}$ & 136 & 12465 & 11749 & $93^{b}$ & $112^{b}$ & 12437 & 11666 & 133 & 104 & $7924^{c}$ & $9030^{c}$ & 48 & 23 \\
\hline
\end{tabular}

798 The effects of crop rotation on maize nitrogen use and economic optimums were calculated based on the regression models

799 shown in Figure 3 and not extrapolated beyond $192 \mathrm{~kg} \mathrm{~N} \mathrm{ha}^{-1}$. Estimates within each variable followed by similar letter or

800 no letters were not significantly different at $p=0.05 .\left(^{*}\right)$ Indicates significant tillage effect at $p=0.05$. Abbreviations: Nmaxy

$801=$ Nitrogen rates at maximum grain yield; $\mathrm{Y}_{\mathrm{Nmax}}=$ Grain yields at Nmaxy; MERN = Maximum Economic Rate of Nitrogen;

$802 \mathrm{MEY}=$ Maximum Economic Yield (estimated grain yield at MERN), PFPERN $=$ Partial Factor Productivity for $\mathrm{N}$ fertilizer at

803 MERN (MEY/MERN); $\mathrm{Y}_{\mathrm{N}=0}=$ Yield at N=0, AE $\mathrm{MERN}_{\mathrm{M}}=$ Agronomic Efficiency of $\mathrm{N}$ fertilizer at MERN $\left(\left(\mathrm{MEY}-\mathrm{Y}_{\mathrm{N}=0}\right) / \mathrm{MERN}\right) ; \mathrm{M}$

$804=$ Maize $; \mathrm{S}=$ Soybean; $\mathrm{W}=$ Winter Wheat; $\mathrm{Wrc}=$ Winter Wheat underseeded with red clover. 
805 Table A.1. Planting and harvest dates of cultivars from 2009 to 2013.

\begin{tabular}{lllll} 
& Crop year & Planting date & Harvest date & Cultivar \\
\hline Maize & 2009 & 25 May & 24 Nov & Pioneer 35F40 \\
& 2010 & 27 May & 12 Nov & Pioneer 37V63 \\
& 2011 & 8 June & 14 Nov & Pioneer P0474HR \\
& 2012 & 26 April & 14 Nov & Pioneer P0891XR \\
& 2013 & 14 May & 7 Nov & Pioneer P0891XR \\
\hline Soybean & 2009 & 25 May & 13 Oct & NK S21-N6 \\
& 2010 & 31 May & 7 Oct & Dekalb DKC30-07 \\
& 2011 & 8 June & 7 Oct & Pioneer 92Y30 \\
& 2012 & 23 May & 28 Sept & Pioneer 92Y30 \\
& 2013 & 22 May & 25 Sept & Pioneer 91Y81 \\
\hline Winter Wheat & 2009 & 15 Oct & 29 July & Pioneer 25R47 \\
& 2010 & 14 Oct & 15 July & Pioneer 25R47 \\
& 2011 & 19 Oct & 14 July & Pioneer 25R56 \\
& 2012 & 2 Nov & 10 July & Pioneer 25R40 \\
& 2013 & 3 Oct & 16 July & Pioneer 25R40 \\
\hline
\end{tabular}

807

808

809

810

811

812

813

814

815

816

817

818 